Article

\title{
Understanding Assessment Processes for Communicative Competence through an Analysis of Teachers' Reported Practice
}

\author{
Fernando Guzmán-Simón ${ }^{1, * \mathbb{D}}$, Juan Jesús Torres-Gordillo ${ }^{2}$ and Katia Caballero ${ }^{3}$ \\ 1 Department of Language Education, Facultad de Ciencias de la Educación, Universidad de Sevilla, \\ 41013 Sevilla, Spain \\ 2 Department of Educational Research Methods and Diagnostics, Facultad de Ciencias de la Educación, \\ Universidad de Sevilla, 41013 Sevilla, Spain; juanj@us.es \\ 3 Department of Didactics and School Organization, Facultad de Ciencias de la Educación, \\ Universidad de Granada, 18071 Granada, Spain; kaballero@ugr.es \\ * Correspondence: fernandoguzman@us.es
}

Received: 26 March 2020; Accepted: 20 April 2020; Published: 22 April 2020

\begin{abstract}
This research addresses the types of assessment tasks, the assessment criteria, instruments and procedures of communicative competence used by primary school teachers in Andalusia. This multiple-case study drew on the experiences of teachers from four schools in the south of Spain. The data source has been the focus groups in which the teachers took part. The transcripts were analysed thematically by three researchers who devised a system of categories designed through an iterative process. The findings reveal the paucity of tasks used to assess reading, listening and oral expression. The study also shows the diverse problems faced by teachers when it comes to evaluating communicative competence. This paper highlights the need to rethink the curricular contents and the methods applied to assess communicative competence in primary schools.
\end{abstract}

Keywords: primary education; communicative competence; assessment literacy; assessment for learning

\section{Introduction}

The implementation of international assessment tests (Programme for International Student Assessment -PISA-, Trends in International Mathematics and Science Study-TIMSS- and Progress in International Reading Literacy Study-PIRLS) led, by the end of the 90s, to the development of the Project of Definition and Selection of Competences (DeSeCo). Its aim was to provide a framework of nine competences to improve learning assessment. Some years later, the European Parliament and Council called on its member countries to develop lifelong learning strategies through incorporating eight key competences into Basic Education. Spain inserted the term basic competences for the first time in the Law of Education (2006) [1] and they were redefined in the Law of Improvement of Quality of Education (2013) [2]. Communicative competence was one of the basic competences, defined as the ability to identify, understand, express, create and interpret concepts, feelings, facts and opinions in both oral and written forms, using visual, sound/audio and digital materials across disciplines and contexts. It implies the ability to communicate and connect effectively with others in an appropriate and creative way [3].

There have been various definitions of communicative competence in the last few decades [4-10]. In 2001 the European Council developed the Common European Framework of Reference for Languages [11], aiming to generate an international reference document for the teaching, learning and assessment of communicative competence. This framework provides standards that, on the one hand, must be 
achieved at different stages of learning and, on the other hand, serve to assess the results in a comparable manner at an international level. It also details the competences required for the communication, knowledge and skills associated with those competences, the situations and domains of communication, as well as the levels of achievement in listening, reading, speaking and writing.

The communicative competence may be understood as the development of listening, reading, speaking and writing through the interaction of different components, such as the linguistic (lexical, grammatical, semantic and phonological dimensions), the pragmatic-discursive (sociolinguistic and pragmatic suitability of the discourse to the different situation contexts), the socio-cultural (the discursive genre chosen in each communicative situation) and the strategic (integration of non-linguistic and multimodal components along with linguistic ones) [12]. The development of the communicative competence requires the acquisition of a meta-discursive awareness in children. According to the schemes proposed by Van Dijk and Kintsch [13] and Halliday [14] shown in Table 1, this metacognitive awareness described by Johns [15] and Rose and Martin [16] enables the further development and accurate use of different discourse levels by speakers, such as the textual microstructure [17], the textual macrostructure [18] and the genre $[19,20]$.

Table 1. Relations between genre, textual structure and language levels.

\begin{tabular}{|c|c|c|}
\hline Textual Structure & Language Levels & Text Descriptor \\
\hline A. Genres & A. Text & $\begin{array}{l}\text { Basic models of text building according to their field, tenor } \\
\text { (to whom it is addressed) and mode (medium of release), } \\
\text { configured by use through History. They have specific pragmatic, } \\
\text { structural and linguistic conventions. }\end{array}$ \\
\hline \multirow{3}{*}{ B. Macrostructures } & B.1. Theme & $\begin{array}{l}\text { The topic and intentionality of the author summarised by the } \\
\text { main idea of the discourse. }\end{array}$ \\
\hline & $\begin{array}{l}\text { B.2. Structures } \\
\text { and stages }\end{array}$ & $\begin{array}{l}\text { The different parts of the text are interconnected, conforming } \\
\text { a thematic progression. It allows the theme of the text to expand } \\
\text { in subthemes, and the different narrative, descriptive or expositive } \\
\text { sequences to progress. According to its genre, the text displays } \\
\text { a structure enabling it to be identified as belonging to } \\
\text { a particular genre. }\end{array}$ \\
\hline & B.3. Cohesion & $\begin{array}{l}\text { The linguistic elements facilitating the global and lineal coherence } \\
\text { of the oral and written text to be displayed. The linguistic tools } \\
\text { that make it possible are: } \\
\text { a. References; } \\
\text { b. Substitutions; } \\
\text { c. Ellipsis; } \\
\text { d. Theme and rheme; } \\
\text { e. Conjunction. }\end{array}$ \\
\hline \multirow{2}{*}{ C. Microstructures } & $\begin{array}{l}\text { C.1. Clauses and } \\
\text { sentences }\end{array}$ & $\begin{array}{l}\text { This level addresses the accuracy of the syntactic construction and } \\
\text { its relation with the genre or textual sequence it belongs to. }\end{array}$ \\
\hline & C.2. Words & $\begin{array}{l}\text { Lexical level addresses the words choice from a lexical-semantic } \\
\text { perspective (paradigmatic axis). }\end{array}$ \\
\hline
\end{tabular}

A detailed analysis of the process followed by those European countries integrating the competences into their curricula was carried out by Arjomand et al. [21], Gordon et al. [22] and Halász and Michel [23]. In the case of Spain, the inclusion of communicative competence in the school curriculum has resulted in some imbalances between either, the curriculum design and the teaching and learning processes carried out by primary education teachers. These imbalances have their origin in the way in which the competences were introduced into the curriculum [24-27]. The key competences have not been incorporated as the central integrative curricular axis, but they have been just added to the existing curriculum. In this way, the purpose of the competences has not been to redesign the teaching and learning processes, but to meet the European guidelines. As a consequence 
of this superficial fit, the subject areas and the assessment standards continue focused on the contents of school subjects and not on the competences [28-33]. The last Spanish educational law in 2013 [2] reduced the role of key competences even more, compared to the legislation of 2006 [1], conceiving them more as capacities than as features applicable to all disciplines [34].

Along with the scarce policies aiming for a full integration of the competences in the Spanish education system, the teachers' training to develop and assess them becomes an added difficulty. Teachers either have little awareness of the available training in communicative competence or do not see it as valuable $[35,36]$, especially in terms of how to assess it [37]. Teachers have little background in the techniques and instruments used to assess competences, and they state that they are not very motivated to carry out these tasks [38]. Furthermore, it has been found that trainee teachers do not learn how to embed the key competences in the school curriculum [39,40].

The assessment of communicative competence is currently one of the Spanish education system's challenges. Numerous authors have put forward proposals to integrate assessment into curriculum design in general [41-49] and communicative competence in particular [50-52]. The improvement in the competences requires new assessment procedures, the development of more precise measurement techniques with more people involved in the assessment and a greater balance between what needs to be measured and what can be measured [53]. It is essential that this assessment is systematically connected with teaching [54], and becomes the driving force for educational improvement $[55,56]$.

The importance of teachers' initial training in teaching the key competences has been underlined by the EU High Level Group of Experts on Literacy [57], who point out that "Prospective teachers should be taught detailed subject-specific knowledge about literacy [ ... ], general pedagogical skills $[\ldots]$, and a wide range of literacy-specific teaching strategies [ ... ]; they should also be taught appropriate assessment techniques and how to diagnose and address reading problems" (p. 44).

The process of implementing the key competences, in general, and communicative competence in particular, was initiated more than a decade ago. Some previous research, such as that by Ramírez [35], Pepper [47] and Halász and Michel [23], has noted the lack of evidence among the EU member states about three fundamental aspects: one, the systematic assessment of the results of the competences implementation process; two, the teachers' training; and three, the role of the school inspector. Our research set out to review, from the teachers' perspective, how educational practice relating to communicative competence is currently being implemented, starting with the following two questions:

RQ1: What kind of assessment tasks related to communicative competence do children carry out in the classroom?

RQ2: What criteria, instruments and assessment procedures of communicative competence do teachers use in the classroom to assess the children?

\section{Method}

Our article addresses the research as a multiple-case study [58], with a descriptive and exploratory aim. To this end, a thematic analysis was carried out $[59,60]$ thereby determining a series of choices concerning the research's design and analysis. The first of these choices is an analysis from the critical realism perspective, as it adopts different valid perspectives concerning the same event [61].

\subsection{Participants}

Four primary schools in Andalusia (south Spain) took part in this case study. The schools were selected according to four criteria. The first criterion was the selection of schools set in urban centres but with different social contexts. The second was that the selected schools should include both public and private. A third criterion was that schools should show different levels of performance. Finally, the four schools should have between 250 and 500 children, and six to twelve teachers. Table 2 shows the specific characteristics of each school. 
Table 2. Characteristics of the participant schools.

\begin{tabular}{cl}
\hline School & \multicolumn{1}{c}{ Characteristics } \\
\hline School 1 & $\begin{array}{l}\text { Low performing public school, whose families have low socio-economic status (SES) } \\
\text { (250 students approximately and 6 teachers). }\end{array}$ \\
School 2 & $\begin{array}{l}\text { Low performing public school, whose families have a medium to low SES (250 students } \\
\text { approximately and 6 teachers). }\end{array}$ \\
School 3 & $\begin{array}{l}\text { Middle-performing private school and a medium to low SES (500 students approximately } \\
\text { and 12 teachers). } \\
\text { Bilingual private school, whose families have a medium to high SES (500 students } \\
\text { approximately and 12 teachers). }\end{array}$ \\
\hline
\end{tabular}

The schools were deliberately chosen. Once they were informed about the aims of the research, they showed special interest in taking part in it. Apart from these four centres, another two schools were initially reached, although they finally refused to participate due to technical problems-the required internet connection-and their lack of time to pursue the teacher training period included in the research.

All the participants in the research were adults, were informed about the nature of the study and the conditions of their participation. The participation was voluntary and followed the rules of informed consent. This investigation has gained approval from and adhered to the standards of the Social Sciences of the Ethical Committee of Experimentation of the University of Seville.

\subsection{Data Analysis}

The data were gathered from focus groups [62] in which teachers from the participant, schools took part. These groups were audio recorded, and subsequently transcribed [63] and analysed using the Atlas-ti, version 6.2 software. The data analysis procedure set out from the elaboration of a coding system based on a theoretical construct [64], although different codes, which emerged during the analysis process, were also incorporated. Therefore, the final system of categories was the result of a hybrid system of deductive-inductive categories [65].

Oral discourse analysis requires a thorough reading of transcriptions, both thematic and content analysis [66]. The analysis unit chosen was the wording, given that oral communication does not always allow sentences to be clearly delimited. The coding system was designed through an iterative process in two repetitions, with the participation of three researchers. In each iteration, the agreement between the coders was calculated using Fleiss's Kappa technique [67], with the aim of reducing the bias in the analyses. The calculations were done with SPSS software (version 24), applying the syntax of Fleiss's Kappa MKAPPASC.SPS designed by David Nichols in 1997. The categories and their indicators were numbered in order to speed the coding process, and to facilitate the subsequent data entry in SPSS. Each researcher coded the sentences assigning a number according to the identified indicator. In the data matrix generated for the analyses there were three columns-one for each researcher-and as many rows as codings. Thus, each row captured the numbers (indicators) assigned by each researcher to every single coding.

Process coding started with an initial coding of focus group 1, for which the consistency of agreement between coders was calculated. The calculated value that did not surpass 0.50 was interpreted as fair [67] or moderate [68]. As a result, the coding system was re-elaborated, and the first focus group was recoded until a fine degree of agreement according to Fleiss [67] and Altman [68] was obtained (see Table 3). Thereafter, the same coding system was applied to the remaining three focus groups, obtaining an agreement $(K>0.94)$ at a level that may be considered very good [68] or excellent [67]. 
Table 3. Calculation of Kappa.

\begin{tabular}{ccccc}
\hline & Kappa (K) & ASE & Z-Value & P-Value \\
\hline Focus group 1 & 0.64756494 & 0.01273862 & 50.83477236 & 0.000000 \\
Focus group 2 & 0.95541310 & 0.00874654 & 109.2332684 & 0.000000 \\
Focus group 3 & 0.96526280 & 0.01459900 & 66.11843498 & 0.000000 \\
Focus group 4 & 0.94163954 & 0.00793460 & 118.6751267 & 0.000000 \\
\hline K = Kappa value; ASE = asymptotic standard error; $Z$ = standardised values; $P$-value $=$ significance 2-tailed.
\end{tabular}

The final coding system consisted of five categories, shown in Table 4, along with their respective indicators (see Table 4).

Table 4. The system of categories of communicative competence for the speaking, listening, reading and writing dimensions.

\begin{tabular}{|c|c|c|}
\hline Category & Indicator & Description \\
\hline \multirow{2}{*}{ Syllabus } & Syllabus & $\begin{array}{l}\text { Types of syllabus and elements, which incorporate } \\
\text { communicative competence (oral and written expression and } \\
\text { comprehension). }\end{array}$ \\
\hline & $\begin{array}{l}\text { Methodological principles } \\
\text { and strategies }\end{array}$ & $\begin{array}{l}\text { Methodological principles and didactic strategies, which } \\
\text { improve communicative competence (oral and written } \\
\text { expression and comprehension). }\end{array}$ \\
\hline \multirow{3}{*}{$\begin{array}{l}\text { Tasks and } \\
\text { activities }\end{array}$} & Types of classroom tasks & $\begin{array}{l}\text { Tasks and activities are carried out to develop competence in } \\
\text { the children's oral and written communication. }\end{array}$ \\
\hline & Resources required & $\begin{array}{l}\text { School resources used for the development of oral and written } \\
\text { communication (school materials required). }\end{array}$ \\
\hline & $\begin{array}{l}\text { Types of classroom tasks } \\
\text { (other curricular areas) }\end{array}$ & $\begin{array}{l}\text { Tasks and activities for oral and written communication in } \\
\text { other curricular areas. }\end{array}$ \\
\hline \multirow{3}{*}{ Assessment } & $\begin{array}{l}\text { Criteria and indicators of } \\
\text { assessment }\end{array}$ & $\begin{array}{l}\text { Indicators of assessment pointed out by the teachers when } \\
\text { doing the assessment of a task aimed to improve linguistic } \\
\text { communication. }\end{array}$ \\
\hline & Assessment instruments & $\begin{array}{l}\text { Instruments used by teachers to assess oral and written } \\
\text { communication. }\end{array}$ \\
\hline & Assessment procedures & Oral and written communication in the classroom. \\
\hline \multirow[t]{2}{*}{ Difficulties } & Teaching difficulties & $\begin{array}{l}\text { Difficulties in the teaching and learning process of oral and } \\
\text { written communication. }\end{array}$ \\
\hline & Assessment difficulties & Difficulties in assessment of oral and written communication. \\
\hline \multirow{3}{*}{$\begin{array}{l}\text { Family } \\
\text { environment }\end{array}$} & Learning difficulties & $\begin{array}{l}\text { Influence of the families in the development of communicative } \\
\text { competence. }\end{array}$ \\
\hline & Learning cooperation & $\begin{array}{l}\text { Tasks carried out by families to improve communicative } \\
\text { competence. }\end{array}$ \\
\hline & Teaching collaboration & $\begin{array}{l}\text { Teaching collaboration for the development of communicative } \\
\text { competence. }\end{array}$ \\
\hline
\end{tabular}

\section{Findings and Discussion}

The findings have been structured with reference to the two main research questions, centred on the types of tasks and the assessment of communicative competence. Each of these includes, firstly, a descriptive analysis based on the frequencies of the codes generated in the system of categories and, secondly, a content analysis of the focus group transcripts. The analysis of the prevalence of codes (see Table 5) enables us to construct numerous statements concerning the practices of the teachers in the classroom. Table 5 shows all the codings performed, both for each code and for each school (S. 1, S. 2, S. 3 and S. 4). The percentages highlighted in grey are the most remarkable data for our research, taking 
every school into account. The interpretation of these results is unpacked below, giving response to the research questions of our study.

\subsection{RQ 1: What Kinds of Assessment Tasks Related with the Communicative Competence Do the Children Carry out in the Classroom?}

\subsubsection{Writing Tasks}

The descriptive analysis based on the categories' frequencies demonstrates a common profile of the practices applied by teachers in the teaching and learning process. In particular, the most frequent types of tasks are related to writing. The most prevalent types of writing tasks in the classroom are copying, handwritten work and dictations ("In their notebook, they write the title of the text, they copy it ... and also, very often, they retain the accents" [School 2]). These tasks are connected with the development of writing skills focused on formal aspects, spelling and the grapheme-phoneme relation of writing in their mother tongue. Likewise, teachers describe a writing model based on the "knowledge telling" [69], where students do not create new thinking (which would require them to "express it in their own words" [School 2]), but literally copy or elaborate information from other sources ("I force them to handwrite it, so it's not printed, and then they elaborate a little, and when they do it using slides, a presentation, then they do work that involves more synthesis, both reading and synthesising the ideas" [School 1]). The development of communicative competence remains, as they had underlined Rose and Martin [16] and Donahue and Lillis [70], focused on the area of writing, since the students' tasks do not encourage the development of the textual macrostructure and the genre. The teachers' writing strategies do not offer the opportunity to develop the complete writing process. Instead, they rely on the fulfilment of a task, but do not approach the meta-discursive background needed to carry it out.

The teachers' concern about writing is oriented towards formal aspects such as spelling ("[he or she] does the readings, does the dictations, and I focus on what would be perhaps more the syllabus of spelling rules ... " [School 2]; “I say, for instance, work on the grammar, the spelling rules” [School 3]), punctuation marks and formal aspects of the written discourse:

In the writing and creation of written texts (...) they tend not to use many punctuation marks. As to spelling, they also make some spelling mistakes. Especially the accents. We work on this by copying, through dictations and by emphasising it a lot. (School 2)

The abundance and diversity of writing tasks contrasts with the lack of tasks related to reading, speaking and listening. The prevalence of written tasks is 1.5 times the tasks related to oral communication (see Table 5). In fact, the teachers demand writing tasks from their students even when they are dealing with the reading, speaking and listening dimensions. The tasks proposed by these teachers are connected in one way or another with writing. As a result, there are few tasks to specifically develop reading, oral expression and comprehension skills. Writing tasks rarely encourage the development of macrostructure skills or genre awareness ("they have a diary and they take it home, for instance, my favourite animal, then they have to draw their favourite animal, what its name is, and they present it in front of their colleagues" [School 1]). The mixture of written and oral communication does not allow for feedback aimed at improving writing in a specific genre. When this type of task is performed, it is decontextualised, thus not addressing real communicative needs, and not reflecting on the situational or cultural context. To sum up, it excludes from learning those elements which conform to the sociocultural learning of genres [71], focusing more on the cognitive process ("in each unit we work on a text; we are currently working on notices, then we'll work on what a note is, what a description is, that's it, we spend 15 days doing descriptions of people" [School 3]). 
Table 5. Frequencies and total percentages of the categories by school.

\begin{tabular}{|c|c|c|c|c|c|c|c|c|c|c|c|}
\hline \multirow[t]{2}{*}{ Competences } & \multirow[t]{2}{*}{ Category } & \multirow[t]{2}{*}{ Indicator } & \multicolumn{9}{|c|}{ Cases } \\
\hline & & & S. 1 & $\%$ & S. 2 & $\%$ & S. 3 & $\%$ & S. 4 & $\%$ & Total \\
\hline \multirow{10}{*}{$\begin{array}{c}\text { Oral } \\
\text { communication } \\
\text { (speaking and } \\
\text { listening) }\end{array}$} & \multirow{2}{*}{ Syllabus } & Syllabus & 7 & 35.0 & 7 & 35.0 & 6 & 30.0 & 0 & 00.0 & 20 \\
\hline & & Methodological principles and strategies & 8 & 25.8 & 12 & 38.7 & 7 & 22.6 & 4 & 12.9 & 31 \\
\hline & \multirow{3}{*}{$\begin{array}{l}\text { Tasks and } \\
\text { activities }\end{array}$} & Types of classroom tasks & 12 & 38.7 & 8 & 25.8 & 4 & 12.9 & 7 & 22.6 & 31 \\
\hline & & Resources required & 6 & 33.3 & 4 & 22.2 & 8 & 44.4 & 0 & 00.0 & 18 \\
\hline & & Types of classroom tasks (other curricular areas) & 5 & 27.8 & 3 & 16.7 & 9 & 50.0 & 1 & 5.6 & 18 \\
\hline & \multirow{3}{*}{ Assessment } & Criteria and indicators of assessment & 7 & 43.7 & 0 & 00.0 & 4 & 25.0 & 5 & 31.3 & 16 \\
\hline & & Assessment instruments & 4 & 57.1 & 0 & 00.0 & 3 & 42.9 & 0 & 00.0 & 7 \\
\hline & & Assessment procedures & 11 & 42.3 & 5 & 19.2 & 7 & 26.9 & 3 & 11.5 & 26 \\
\hline & \multirow{2}{*}{ Difficulties } & Teaching difficulties & 8 & 22.9 & 15 & 42.9 & 9 & 25.7 & 3 & 8.6 & 35 \\
\hline & & Assessment difficulties & 3 & 100 & 0 & 00.0 & 0 & 00.0 & 0 & 00.0 & 3 \\
\hline \multirow{10}{*}{$\begin{array}{l}\text { Written } \\
\text { communication } \\
\text { (Reading) }\end{array}$} & \multirow{2}{*}{ Syllabus } & Syllabus & 4 & 16.7 & 11 & 45.8 & 8 & 33.3 & 1 & 4.2 & 24 \\
\hline & & Methodological principles and strategies & 4 & 10.0 & 11 & 27.5 & 14 & 35.0 & 11 & 27.5 & 40 \\
\hline & \multirow{3}{*}{$\begin{array}{l}\text { Tasks and } \\
\text { activities }\end{array}$} & Types of classroom tasks & 9 & 20.9 & 16 & 37.2 & 8 & 18.6 & 10 & 23.3 & 43 \\
\hline & & Resources required & 7 & 23.3 & 13 & 43.3 & 9 & 30.0 & 1 & 3.3 & 30 \\
\hline & & Types of classroom tasks (other curricular areas) & 3 & 17.6 & 3 & 17.6 & 10 & 58.8 & 1 & 6.0 & 17 \\
\hline & \multirow{3}{*}{ Assessment } & Criteria and indicators of assessment & 4 & 30.8 & 0 & 00.0 & 6 & 46.1 & 3 & 23.1 & 13 \\
\hline & & Assessment instruments & 0 & 00.0 & 0 & 00.0 & 4 & 100 & 0 & 00.0 & 4 \\
\hline & & Assessment procedures & 0 & 00.0 & 7 & 46.7 & 8 & 53.3 & 0 & 00.0 & 15 \\
\hline & \multirow{2}{*}{ Difficulties } & Teaching difficulties & 5 & 11.9 & 15 & 35.7 & 16 & 38.1 & 6 & 14.3 & 42 \\
\hline & & Assessment difficulties & 0 & 00.0 & 0 & 00.0 & 0 & 00.0 & 0 & 00.0 & 0 \\
\hline
\end{tabular}


Table 5. Cont

\begin{tabular}{|c|c|c|c|c|c|c|c|c|c|c|c|}
\hline \multirow[t]{2}{*}{ Competences } & \multirow[t]{2}{*}{ Category } & \multirow[t]{2}{*}{ Indicator } & \multicolumn{9}{|c|}{ Cases } \\
\hline & & & S. 1 & $\%$ & S. 2 & $\%$ & S. 3 & $\%$ & S. 4 & $\%$ & Total \\
\hline \multirow{10}{*}{$\begin{array}{c}\text { Written } \\
\text { communication } \\
\text { (writing) }\end{array}$} & \multirow{2}{*}{ Syllabus } & Syllabus & 4 & 18.2 & 7 & 31.8 & 9 & 40.9 & 2 & 9.1 & 22 \\
\hline & & Methodological principles and strategies & 3 & 10.7 & 11 & 39.3 & 10 & 35.7 & 4 & 14.3 & 28 \\
\hline & \multirow{3}{*}{$\begin{array}{l}\text { Tasks and } \\
\text { activities }\end{array}$} & Types of class tasks & 10 & 22.2 & 12 & 26.7 & 15 & 33.3 & 8 & 17.8 & 45 \\
\hline & & Resources required & 3 & 20.0 & 4 & 26.7 & 7 & 46.7 & 1 & 6.6 & 15 \\
\hline & & Types of classroom tasks (other curricular areas) & 3 & 13.6 & 2 & 9.1 & 12 & 54.6 & 5 & 22.7 & 22 \\
\hline & \multirow{3}{*}{ Assessment } & Criteria and indicators of assessment & 6 & 22.2 & 3 & 11.1 & 6 & 22.2 & 12 & 44.4 & 27 \\
\hline & & Assessment instruments & 4 & 36.4 & 1 & 9.1 & 4 & 36.4 & 2 & 18.2 & 11 \\
\hline & & Assessment procedures & 4 & 13.3 & 15 & 50.0 & 9 & 30.0 & 2 & 6.7 & 30 \\
\hline & \multirow{2}{*}{ Difficulties } & Teaching difficulties & 9 & 25.0 & 16 & 44.5 & 8 & 22.2 & 3 & 8.3 & 36 \\
\hline & & Assessment difficulties & 1 & 33.3 & 0 & 00.0 & 0 & 00.0 & 2 & 66.7 & 3 \\
\hline \multirow{3}{*}{$\begin{array}{c}\text { Family } \\
\text { environment and } \\
\text { school } \\
\text { organisation }\end{array}$} & \multirow{3}{*}{$\begin{array}{c}\text { Family } \\
\text { environment }\end{array}$} & Learning difficulties & 0 & 00.0 & 6 & 37.5 & 6 & 37.5 & 4 & 25.0 & 16 \\
\hline & & Learning cooperation & 0 & 00.0 & 2 & 20.0 & 7 & 70.0 & 1 & 10.0 & 10 \\
\hline & & Teaching coordination & 3 & 13.6 & 17 & 77.3 & 2 & 9.1 & 0 & 00.0 & 22 \\
\hline
\end{tabular}


Teachers design tasks mainly for the purpose of the development of textual cohesion and coherence (macrostructure). As Rose [72] had pointed out, the classroom tasks are not oriented towards the improvement of textual structure, its adequacy for the genre and the communicative situation, and the development of self-regulation when writing that require metacognitive ability. The limited emphasis is illustrated here:

That everything is coherent, that they use appropriate words. (...) That they write it, that it's well written, that it has its parts (its beginning, its denouement ... ). For them, to be a bit more autonomous. (School 2)

Exceptionally, teachers make use of scaffolding for the development of textual structure as recommended by Martin [73]. There is an example in the focus groups related to the narrative text ("Keeping the parts of the beginning, the hub and the denouement. (... ) And with the parts very structured, they know what they have to do. That's to say, it isn't 'I write to write'" [School 4]) and the expository text ("they know it and they associate it, and they know where they have to go, it's with the conceptual maps we do. For example, a conceptual map for the description of objects" [School 3]). These tasks enable the development of the textual macrostructure and genre awareness. Nevertheless, the use of scaffolding tends to predominate in tasks oriented to narrative and descriptive texts:

(... ) I've always tried to do a literary creation workshop (... ) and I try to do it from inconclusive texts, which they add an end to, from giving them a structure about a story (... ) so based on a model which has been accepted in general quite well, they create one imitating it. (School 1)

In summary, the classroom tasks encourage reading, but without the development of the textual macrostructure. Our results show the difficulties faced in the classrooms when teachers deal with the improvement of textual cohesion and coherence ("we, in second grade, we've realised that it's hard for them to write, for example, when doing a summary. It's very hard for them, the written expression, not to get lost. Then, we try to get it to be more structured" [School 4]).

\subsubsection{Reading Tasks}

The participant schools show a greater frequency in the codes which refer to the difficulties of teaching of communicative competence in the classroom, highlighting reading as the most difficult skill. The improvement of reading presents numerous difficulties for the primary school teachers, as the reading tasks do not address the development of specific skills. These tasks are seldom specific, and are mainly related to reading comprehension ("at the beginning of each learning unit, there's a page of [written] activities of comprehensive reading." [School 4]). In general, they are not very specific, and are connected with open answer activities in a notebook.

When specific tasks about reading are tackled, they usually consist of activities of control, speed and oral reading accuracy, but they do not focus on the improvement of reading comprehension or the development of self-regulation of reading (" [... ] one day a week, which is Thursday, [ ... ] I practise with them speed reading. I take my mobile and I time them, and they're enthusiastic about seeing who reads best of all" [School 2]). In fact, the reading tasks tend to be oriented to the completion of reading comprehension worksheets. Consequently, reading tasks do not develop reading self-regulation or strategies to favour reading comprehension:

Once we've read a chapter, then we start to work with the notebook in class. (School 4)

I'm referring to the worksheet, to the traditional book of worksheets for comprehensive reading, of different types of reading, this can be informative, can be literary. (School 1)

And then, when they finish a book (... ) they do a worksheet. (School 2) 
Finally, the improvement of reading (speed, accuracy, etc.) is achieved through reading aloud or through the reading of dramatised texts. These are the most frequent tasks in the schools and, along with comprehensive reading cards, they become the basis of the primary school students' reading improvement.

\subsubsection{Tasks of Expression and Oral Comprehension}

The oral comprehension tasks tend to be present in almost all of the classroom tasks. Nonetheless, oral comprehension skills are not the objective of specific tasks in syllabus. However, some tasks do incorporate oral expression through oral presentations, debates and diverse oral comments related to other reading and writing tasks ("well, we talk, we debate, about magic characters. Since what comes after is creating a story" [School 1]).

To summarise, the tasks for communicative competence require a reformulation of the curriculum, in order to generate an approach based on tasks with different levels of complexity. Moreover, these tasks should be adapted, as Sarramona [26], Moya [45] and Trujillo [74] have suggested, to each level for competency development, in such a way that the students are capable of responding to situations or problems making use of the skills learnt at the school.

\section{2. $R Q$ 2: What Criteria, Instruments and Assessment Procedures of Communicative Competence Do the Teachers Use in the Classroom to Assess the Children?}

\subsubsection{Assessment Criteria and Indicators}

The lowest frequencies in our analysis (below 10) are found in the difficulties in the assessment of the four dimensions of communicative competence, with 0 for reading. This calls into question how the teaching and learning process is developed, inasmuch as, compared to its high frequency in the tasks proposed to the students, we find little evidence of assessment tasks as well as a lack of awareness among teachers about the deficiencies of the assessment of communicative competence. The section dedicated to the indicators concerning the assessment of communicative competence shows considerable differences between the frequencies of assessment "Criteria and indicators", "Instruments" and "Procedures". These three indicators determine the prevalence of the assessment tasks of Writing over Reading (>2) and Speaking and Listening (1.4), and are related to the lack of records for the assessment of communicative competence (see Table 5).

The assessment criteria and indicators of writing are focused on formal aspects, spelling and the normative construction of speech. These three elements are often considered to assess communicative competence. Moreover, these criteria and indicators are linked almost exclusively with the assessment of writing. The indicators associated with the presentation of the handwritten texts of the students become a key element for teachers: "It is ever-present for them to have a good presentation, for them to have it organised, for it to be understandable, for them to leave spaces from question to question and from answer to answer, so it's not all tangled up. So that even at first sight you feel like looking at the notebook" (School 2). This last quote also indicates the lack of consistency in the assessment of formal aspects.

The second aspect highlighted by teachers as an assessment criterion or as an indicator of communicative competence is spelling. Spelling is broadly assessed by teachers and becomes relevant in the stage in primary schools, where writing and reading are being developed from their initial phase ("to see if words are written separately, if they're written together, if they're written correctly" [School 1]). The assessment of spelling does tend to be systematic ("Yes, we have a record maybe of spelling" [School 2]) and tends to be tested through written or dictated exams: "we mark it in written tasks because they are collected (... ) and we always have question, which is a dictation" (School 3).

Finally, criteria and indicators of assessment of communicative competence tend to be less focused on syntax, be it its accuracy or the length of the phrases ("constructing phrases of more than 8 words, for that we do have our set criteria") [School 1]). However, this assessment does not go 
thoroughly into the diversity of types of speech that the student can carry out (e.g., relative subordinates, substantive subordinates, etc.) throughout primary school. The criteria assessing syntax are scant and uniquely assess quantitative aspects, rather than their typology or syntactic complexity. To sum up, the assessment criteria and indicators used by teachers exclude numerous aspects of communicative competence, such as textual structure, the text's coherence and cohesion, as well as its adaptation to numerous aspects related to the genre.

The role of feedback in the assessment of writing [75] consists of written, unelaborated feedback ("all the spelling in red and with marker, for them to see it's all wrong there, the accents, many accents, like crazy" [School 1]), as well as oral feedback, carried out collectively ("it's done publicly for the slides to end up accurately, without spelling mistakes, and this correction is public" [School 1]). In addition, teachers mention other, less frequent forms of feedback, such as asking students to find the mistakes in their own writing ("I often tell them to read out loud, for them to realise that [in] written production everything has [ ... ] to be all strung together. And this also helps them to see that this is somehow another form of expression" [School 4]), and peer assessment and self-assessment ("sometimes, they correct their own work, and at other times they exchange their work with their colleagues'" [School 4]). In general, the feedback on writing is not fully elaborated and has a group dimension [76]. The teachers' reasons for applying non-elaborated feedback is the excessive number of students they have in the classroom, and their inability to handle an individualised assessment: "Our classroom routine ( ... ) is for me to go from desk to desk, glancing at the spelling mistakes. Because obviously, if I correct all the details, I wouldn't have time to teach" [School 2]).

Regarding the reading assessment criteria and indicators, teachers claim to have little knowledge of them [77], naming explicitly only the reading speed assessment ("In reading, sometimes we even get a chronometer and a paragraph, to see how long it takes them to read it, to assess mechanical reading" [School 4]). In general, teachers assess other aspects of reading, without clearly and precisely describing applied criteria ("one day you ask them to read, and today I'm going to mark, or at times reading in public ( ... ) and you give this a mark" [School 4]). On the other hand, oral communication assessment poses a problem stemming from the lack of specific criteria and indicators to assess this competence ("I don't assess, I don't put a mark to that, I don't know if this has a result ( ... ). Then, work, you work a lot, but I go on seeing it all as a bit chaotic" [School 1]). Teachers show little awareness of the need to systematically assess oral expression ("Now you mention it, it doesn't tend to be included in my marks" [School 1]), which leads to a lack of knowledge about how to determine the problems shown in oral expression, and how to intervene for its improvement. Finally, we should point out that none of the participant schools showed concern about oral comprehension assessment.

\subsubsection{Assessment Instruments and Procedures}

Our findings show how that the assessment instruments used in the primary school classrooms are exams, the students' class notebooks, dictations, worksheets provided by educational publishing houses and observation in the classroom. Exams are, in order of frequency, the predominant assessment instrument (" $[. .$. ] you don't really capture it, because later on you set the exam, or correct notebooks, or you ask them, 'hey, write a story', and you value if they're using adjectives, if the phrase has been constructed right, when they tell a story" [School 1]). This circumstance shows how the teachers assess communicative competence almost exclusively using written discourse, as they have numerous doubts and problems in the use of other assessment instruments. Other written instruments used in the classroom are the student's notebook ("then, in the same way you notice in the writing for example, in which a notebook is organised and it's now something legible, you mark it, but you don't pick it up ..." [School 1]), dictations ("We also have, for example, for spelling we have a specific book of spelling [ ... ] and then at the end we have an assessment, a dictation too" [School 4]) and written worksheets provided by publishing houses ("there are also evaluation worksheets from the publishing houses, and I normally use them" [School 1]). The assessment with these instruments tends to be focused on formal and spelling aspects typical of the Spanish language ("written expression and 
spelling with the dictations. And logically well you see how the calligraphy and all the rest is" [School 4]). Likewise, the written expression assessment is devalued, to the extent that texts developed by the students themselves are not used. The teaching and learning process uniquely assume feedback should be oriented towards the improvement of the textual microstructure, abandoning the discourse's communicative dimension [78]. When observation is applied in the classroom, the teachers appear to have several deficits when systematising this assessment through specific assessment indicators and standards:

Really you have a general overview, I give them a general mark for this work which, in the end, doesn't belong to Language, so thereafter I don't reflect it in Language. (School 1)

In brief, assessment in the participant primary schools shows a concentration on the assessment of communicative competence as a product of writing. Also, this writing becomes the common way to assess other dimensions, such as reading and oral communication, as the teachers have not developed the skills to assess the learning processes ("first, looking at their worksheets, their notebooks, their book, and from time to time I take each one aside, and I give them a dictation, to check if, to check if they write the words separately, if they write them together, if they write them correctly" [School 1]). On other occasions, the assessment lacks precise criteria and instruments, leading to the conclusion that judgement of communicative competence may be described as "impressionistic":

I'm observing them all the time [ ... ]. Then I have the child who brings me the homework every day, the child who brings everything very clean and neat, in order (... ). And then, at the end of each term, we also have a global test of all that we've been practising. (School 2)

The different schools have shown an overall mix-up between the concepts of assessment and qualification. This leads, in turn, to assessments that do not focus on improvement, and the feedback received by the students is non-elaborated and not truly connected to the task and its aim. The imprecision of the criteria-and the scarcity of appropriate instruments for the assessment of the learning process in the classroom-show a scant and inefficient assessment of communicative competence in a sample of schools in the south of Spain. Moya and Luengo [25] establish two requirements prior to the beginning of any assessment process: 1 , determine the assessment criteria as valid indicators for each of the competences. In other words, determine the behaviours to be shown by students when performing specific tasks; 2 , plan the tasks aimed to provide the students with the opportunity to acquire and express the competences that are going to be assessed. The completion of these conditions should help to avoid the information gathering process being imprecise and haphazard. If they are not fulfilled, it would be impossible to know what we seek and how to go about seeking it.

\subsubsection{Limitations}

This research has some limitations. One of them has to do with the selection of the number of participant schools. The decision to focus the research on those four schools was based on the difficulty of analysing data obtained in schools showing a huge variety and complexity. The thorough analysis of these data has therefore forced to limit the number of schools involved. A second limitation has been the selection of a region located in the south of Spain. Our interest in studying the south of Spain lies in the fact that it is region with the largest school population and the lowest PIRLS 2016 performance. A third limitation involves the difficulty of accessing the testimonies of primary teachers about the assessment of communicative competence. Teachers were reticent to talk about their experiences when they were asked about their training or assessment experience. This led us to invest a considerable amount of time during the research in obtaining the information needed to approach this issue, and to reduce the sample to four different schools. 


\section{Conclusions}

Our study offers a critical reflection on the complexity of educational practices in communicative competence in the classroom and the teacher's role as facilitator and mediator. Therefore, our results help us to understand the educational context of communicative competence in Spanish teachers. This article's research questions were focused on the types of tasks related to communicative competence and their assessment criteria, the instruments and procedures used by the teachers. First, the tasks associated with communicative competence have shown big disparities, depending on their nature and focus-i.e., whether they were writing, reading, speaking or listening tasks. According to the teachers, classroom tasks tend to be oriented to the improvement of writing and, to a lesser extent, reading. The type of tasks in the classroom acquires a core value in primary education, as the written code of the language becomes a central measure of school success. Yet the omnipresence of oral communication in the classroom does not prevent the speaking and listening dimensions of the communicative competence from being disregarded.

The second question has to do with the criteria, instruments and procedures to assess the communicative competence. The high frequency in the number of tasks does not correspond with the scarcity of evidence in systematic assessment criteria, instruments and procedures. The lack of awareness of assessment tasks and the poverty of techniques and instruments lead to a weak assessment of communicative competence. Therefore, the inclusion of the competences in the curriculum should require a new approach, both in its design and in its development, in such a way that the competences become the axis that gives meaning to and articulates the rest of the elements of the curriculum. Our study, in line with Sierra et al. [27], shows how assessment is carried out on the content and not on the dimensions of communicative competence. As a result, the assessment of communicative competence poses several difficulties for teachers [51].

In conclusion, this research confirms the results of previous studies [79], and delves into the inquiry of the communicative competence. More specifically, our contribution has focused on the nature and types of the tasks undertaken in the classrooms, and on their assessment by the teachers. Our results underpin the necessity of implementing, within the Spanish context [80], the advice from the European Union Council [3]. This advice is oriented towards three main lines of action:

a. A wider diversity of approaches and learning environments in the school;

b. A specific support for teachers, oriented to the training in key competences;

c. An institutional plan aimed to train the teachers in efficient techniques for the assessment of the key competences.

Our research results reveal the differences between the prescriptions of the Spanish curriculum in Ley Orgánica 2/2006 [1] and Ley Orgánica 8/2013 [2], and the tasks and assessment carried out by the primary education teachers nowadays. Like Koh et al. [81], our study shows that teachers should receive the appropriate training in assessment, enabling the development of the curriculum through the competences, and, by doing so, transforming the teaching and learning process for students.

Author Contributions: F.G.-S., J.J.T.-G. and K.C. conceived the research idea and designed the research framework. Conceptualization, K.C. and F.G.-S.; methodology, J.J.T.-G. and F.G.-S.; software, J.J.T.-G. and F.G.-S.; validation, J.J.T.-G.; F.G.-S., J.J.T.-G. and K.C. analysed the data, wrote the draft and approved the final manuscript; project administration, J.J.T.-G.; funding acquisition, J.J.T.-G. All authors have read and agree to the published version of the manuscript.

Funding: This research was funding by the Ministry of Economics and Competitiveness of Spain (grant number EDU2013-44176-P) entitled "Improvement of the Competence in Linguistic Communication of Early Childhood Education and Primary Education". This grant was obtained in a competitive call corresponding to the State Plan of Advancement of Scientific and Technical Research of Excellence, State Subprogram of Generation of Knowledge, of the Secretary of State for Research, Development and Innovation.

Acknowledgments: Ministry of Economics and Competitiveness of Spain.

Conflicts of Interest: The authors declare no conflict of interest. 


\section{References}

1. Ley Orgánica 2/2006, de 3 de Mayo, de Educación [General Education Law 2/2006, 3rd May]. Available online: https://www.boe.es/eli/es/lo/2006/05/03/2/con (accessed on 8 August 2018).

2. Ley Orgánica 8/2013, de 9 de Diciembre, Para la Mejora de la Calidad Educativa [General Education Law 8/2013, 9th December, for the improvement of educational quality]. Available online: https://www.boe.es/eli/ es/lo/2013/12/09/8/con (accessed on 8 August 2018).

3. Council of the European Union. Council Recommendation of 22 May 2018 on Key Competences for Lifelong Learning; Council of the European Union: Brussels, Belgium, 2018; p. 15. Available online: https://eur-lex. europa.eu/legal-content/EN/TXT/PDF/?uri=CELEX:32018H0604(01)\&from=EN (accessed on 8 August 2018).

4. Bachman, L.F. Fundamental Considerations in Language Testing; Oxford University Press: Oxford, UK, 1990; ISBN 0-19-437003-8.

5. Canale, M.; Swain, M. Theoretical bases of communicative approaches to second language teaching and testing. Appl. Linguist. 1980, 1, 1-47. [CrossRef]

6. Celce-Murcia, M. Rethinking the role of communicative competence in language teaching. In Intercultural Language Use and Language Learning; Alcón, E., Safont, M.P., Eds.; Springer: Berlin, Germany, 2007; pp. 41-57, ISBN 978-1-4020-5636-9.

7. Coseriu, E. Competencia Lingüística. Elementos de la Teoría del Hablar [Linguistic Competence. Elements of the Theory of Speaking]; Gredos: Madrid, Spain, 1992; ISBN 84-249-1495-3.

8. Hymes, D. On communicative competence. In Sociolinguistics; Pride, I.B., Holmes, J., Eds.; Penguin Education, Penguin Books Ltd: Baltimore, MD, USA, 1972; pp. 269-293, ISBN 978-0140226584.

9. Savignon, S.J. Communicative Competence: Theory and Classroom Practice. Texts and Contexts in Second Language Learning; Addison-Wesley Publishing Company: Reading, MA, USA, 1983; ISBN 978-00-7083-736-2.

10. Widdowson, H.G. Learning Purpose and Language Use; Oxford University Press: Oxford, UK, 1983; ISBN 0-19-437070-0.

11. Council of Europe. Common European Framework of Reference for Languages: Learning, Teaching, Assessment; Cambridge University Press: Cambridge, UK, 2001.

12. Canale, M. From communicative competence to communicative language Pedagogy. In Language and Communication; Richards, J.C., Smith, R., Eds.; Longman: London, UK, 1983; pp. 2-14.

13. Van Dijk, T.A.; Kintsch, W. Strategies of Discourse Comprehension; Academic Press: Orlando, FL, USA, 1983; ISBN 978-0-12712-050-8.

14. Halliday, M.A.K.; Hasan, R. Language, Context, and Text: Aspects of Language in A Social-Semiotic Perspective; Deakin University Press: Victoria, Australia, 1985; ISBN 978-0-73000-307-6.

15. Johns, A.M. Genre awareness for the novice academic student: An ongoing quest. Lang. Teach. 2008, 41, 237-252. [CrossRef]

16. Rose, D.; Martin, J.R. Learning to write, reading to learn. In Genre, Knowledge and Pedagogy in the Sydney School; Equinox: Sheffield, UK, 2012; ISBN 978-1-84553-143-0.

17. Halliday, M.A.K. Introduction to Functional Grammar; Routledge: London, UK, 2014; ISBN 978-0-41582-628-0.

18. Martin, J.R.; Rose, S. Working with discourse. In Meaning Beyond the Clause; Bloomsbury: London, UK, 2013; ISBN 978-0-8264-8849-7.

19. Bawarshi, A.S.; Reiff, M.J. An Introduction to History, Theory, Research, and Pedagogy; Parlor Press/The WAC Clearinghouse: Indianapolis, IN, USA, 2010; ISBN 978-1-60235-171-4.

20. Martin, J.R.; Rose, D. Genre relations. In Mapping Culture; Equinox: London, UK, 2007; ISBN 978-1-84553-047-1.

21. Arjomand, G.; Erstad, O.; Gilje, O.; Gordon, J.; Kallunki, V.; Kearney, C.; Rey, O.; Siewiorek, A.; Vivitsou, M.; von Reis Saari, J. KeyCoNet 2013 Literature Review: Key Competence Development in School Education in Europe. Available online: http://keyconet.eun.org/literature-review (accessed on 17 May 2019).

22. Gordon, J.; Halász, G.; Krawczyk, M.; Leney, T.; Michel, A.; Pepper, D.; Putkiewicz, E.; Wisniewski, J. Key Competences in Europe: Opening Doors for Lifelong Learners Across the School Curriculum and Teacher Education. Warsaw: CASE, Center for Social and Economic Research. 2009. Available online: http://hdl.handle.net/10419/87621 (accessed on 26 March 2020).

23. Halász, G.; Michel, A. Key competences in Europe: Interpretation, policy formulation and implementation. Eur. J. Educ. 2011, 46, 289-306. [CrossRef] 
24. Guarro, A. Competencias básicas: Currículum integrado y aprendizaje cooperativo [Basic competences: Integrated curriculum and cooperative learning]. Investig. En La Esc. 2008, 66, 29-42. [CrossRef]

25. Moya, J.; Luego, F. La concreción curricular de las competencias básicas: Un modelo adaptativo e integrado [The curricular concretion of the basic competences. An adaptive and integrated model]. CEE Particip. Educ. 2010, 15, 127-141.

26. Sarramona, J. Competencias básicas y currículum. El caso de Cataluña [Basic competences and curricula. The case of Catalonia]. Teor. Educ. 2014, 26, 205-228. [CrossRef]

27. Sierra, B.; Méndez, A.; Mañana, J. La programación por competencias básicas: Hacia un cambio metodológico interdisciplinar [Syllabus through the key competences: Toward an interdisciplinary methodological change]. Rev. Complut. Ee Educ. 2013, 24, 165-184. [CrossRef]

28. Białecki, I.; Jakubowski, M.; Wisniewski, J. Education policy in Poland: The impact of PISA (and other international studies). Eur. J. Educ. 2017, 52, 167-174. [CrossRef]

29. Bolívar, A. Los "nuevos" currículos de ESO y Bachillerato: Caos en cortar y pegar. [The "new" curricula of Secondary School: Cut-and-paste chaos]. Escuela 2014, 4, 36.

30. Bolívar, A. Nuevo currículo básico de Primaria [New basic curriculum in Primary Education]. Escuela 2014, $4,396$.

31. Feito, R. De las competencias básicas al currículum integrado [Of the basic competences in the integrated curriculum]. Rev. Qurriculum 2010, 23, 55-79.

32. Perrenoud, P. Cuando la Escuela Pretende Preparar Para la Vida. ¿Desarrollar Competencias o Enseñar Otros Saberes? [When the School Tries to Prepare for Life. To Develop Competences or to Teach Other Knowledge?]; Graó: Barcelona, Spain, 2012; ISBN 978-84-9980-416-3.

33. Rodríguez-Martínez, C.; Díez, E.J. Conocimiento y competencias básicas en la formación inicial de maestras y maestros [Knowledge and basic competences in initial teacher training]. Profr. Rev. Ee Currículum Form. Del Profr. 2014, 18, 383-396. Available online: http://www.ugr.es/local/recfpro/rev181COL11.pdf (accessed on 26 March 2020).

34. European Commission. Report on A Literature Review of Reforms Related to the 2006 European Framework of Key Competences for Lifelong Learning and the Role of the Framework in These Reforms; European Commission: Brussels, Belgium, 2017; ISBN 978-92-79-77229-0. Available online: https://op.europa.eu/en/publicationdetail/-/publication/bf6739aa-04a8-11e8-b8f5-01aa75ed71a1/language-en (accessed on 26 March 2020).

35. Ramírez, A. Conocimiento de las competencias básicas y valoración del profesorado de Educación Primaria de la orientación recibida sobre las mismas [Knowledge of the basic competences and evaluation of the teachers of primary education of the counseling received about them]. REOP 2011, 22, 329-346.

36. Ramírez, A.; Pérez del Arco, J.M. Legal standards versus school context: Implementation of competencies in primary education. Cult. Educ. 2013, 25, 399-414. [CrossRef]

37. Monarca, H.; Rappoport, S. Investigación sobre los procesos de cambio educativo. El caso de las competencias básicas en España [Research on the process of educational change: The case of key competencies in Spain]. Rev. Educ. 2013, 54-78. [CrossRef]

38. González, I.; Ramírez, A.; Moral, A. La evaluación por competencias en educación primaria: ¿Arquitectura o albañilería? [Competences-based Assessment in Primary Education. Architecture or Masonry?]. Educere 2013, 17, 41-50.

39. De-Juanas, A.; Martín, R.; Pesquero, E. Teaching competences necessary for developing key competences of primary education students in Spain: Teacher assessments. Teach. Dev. 2016, 20, 123-145. [CrossRef]

40. Bagnato, S.J.; McLean, M.; Macy, M.; Neisworth, J.T. Identifying instructional targets for early childhood via authentic assessment: Alignment of professional standards and practice-based evidence. J. Early Interv. 2012, 33, 243-253. [CrossRef]

41. Black, P. Helping students to become capable learners. Eur. J. Educ. 2018, 53, 144-159. [CrossRef]

42. Bolívar, A. Competencias Básicas y Currículo [Basic Competences and Curriculum]; Síntesis: Madrid, Spain, 2010; ISBN 978-8-4975-6706-0.

43. Kordik, A. Does schooling develop the skills needed to make sense of the world? Eur. J. Educ. 2015, 50, 387-390. [CrossRef]

44. Martínez, P.; Echevarría, B. Formación basada en competencias [Competence-based training]. Rev. Investig. Educ. 2009, 27, 125-147. [CrossRef] 
45. Moya, J. La integración de los aprendizajes en la evaluación [The integration of learnings in assessment]. In Proyecto Atlántida. De Las Competencias Básicas Al Currículo Integrado [Project Atlántida. From the Basic Competences to the Integrated Curriculum]; Moya, J.C., Ed.; Proyecto Atlántida: Madrid, Spain, 2008; ISBN 978-84-691-5352-9.

46. Vázquez, P.; Ortega, J.L. Competencias Básicas: Desarrollo y Evaluación en Educación Primaria [Basic Competences: Development and Assessment in Primary Education]; Wolters Kluwer: Madrid, Spain, 2011; ISBN 978-84-7197-975-9.

47. Pepper, D. Assessing key competences across the curriculum-And Europe. Eur. J. Educ. 2011, 46, 335-353. [CrossRef]

48. Pepper, D. KeyCoNet 2013 Literature review: Assessment of Key Competences. 2013. Available online: http://keyconet.eun.org/literature-review (accessed on 8 April 2018).

49. Polo, I. La evaluación de las competencias básicas [The assessment of the basic competences]. Av. En Supervisión Educ. 2010, 12,1-11. Available online: https://avances.adide.org/index.php/ase/article/view/440 (accessed on 26 March 2020).

50. Fernández, S. Evaluación de la competencia comunicativa, desarrollo curricular y MCER. In Proceedings of the FIAPE. II Congreso Internacional: Una Lengua, Muchas Culturas [Assessment of the Communicative Competence, Curricular Development and MCER. FIAPE. II International Congress: One Language, Many Cultures], Granada, Spain, 26-29 September 2007. Available online: https://www.mecd.gob.es/dam/jcr: b8531fd1-a7b6-4015-92eb-cbda0abf5875/2007-esp-12-05fernandez-pdf.pdf (accessed on 8 August 2018).

51. Griffith, W.I.; Lim, H.Y. Introduction to competency-based language teaching. MEXTESOL J. 2014, 38, 1-8.

52. Neira, M.R.; Sierra, B.; Pérez-Ferra, M. La competencia comunicativa en el Grado de Maestro/a en Educación Infantil y Primaria. Una propuesta de criterios de desempeño como referencia-marco para su análisis y evaluación [Communicative competence in the Degree in Early Childhood Education and the Degree in Primary Education Teacher. A proposal of achievement criteria as a tool for their analysis and assessment]. Rev. Complut. Educ. 2018, 29, 881-898. [CrossRef]

53. Carneiro, R.; Looney, J.; Vincent-Lancrin, S. Learning from the past, looking to the future: Issues and agendas in education. Eur. J. Educ. 2015, 50, 524-535. [CrossRef]

54. Baker, E. Design for assessment change. Eur. J. Educ. 2018, 53, 138-140. [CrossRef]

55. Looney, J. Are student assessments fit for their purposes? Eur. J. Educ. 2018, 53, 129-132. [CrossRef]

56. Wiliam, D. Assessment and learning: Some reflections. Assess. Educ. Princ. Policy Pract. 2017, $24,394-403$. [CrossRef]

57. EU High Level Group of Experts on Literacy. Final Report of the EU High Level Group of Experts on Literacy Luxembourg. 2012. Available online: http://ec.europa.eu/dgs/education_culture/repository/education/policy/ school/doc/literacy-report_en.pdf (accessed on 8 August 2018).

58. Yin, R.K. Case Study Research: Design and Methods; Sage: London, UK, 2014; ISBN 978-1-4129-6099-1.

59. Braun, V.; Clarke, V. Using thematic analysis in psychology. Qual. Res. Psychol. 2006, 3, 77-101. [CrossRef]

60. Tuckett, A.G. Applying Thematic Analysis Theory to practice: A researcher's experience. Contemp. Nurse 2005, 19, 75-87. [CrossRef] [PubMed]

61. Maxwell, J. A Realist Approach for Qualitative Research; SAGE: Thousand Oaks, CA, USA, 2012; ISBN 978-0761929239.

62. Barbour, R. Analysing focus groups. In The SAGE Handbook of Qualitative Data Analysis; Flick, U., Ed.; Sage: London, UK, 2014; pp. 313-326, ISBN 978-1-4462-0898-4.

63. Kowal, S.; O'Connell, D.C. Transcription as a crucial step of data analysis. In The SAGE Handbook of Qualitative Data Analysis; U. Flick, Ed.; SAGE: London, UK, 2014; pp. 64-78, ISBN 978-1-4462-0898-4.

64. Varpio, L.; Ajjawi, R.; Monrouxe, L.V.; O’Brien, B.C.; Rees, C.E. Shedding the cobra effect: Problematising thematic emergence, triangulation, saturation and member checking. Med. Educ. 2017, 51, 40-50. [CrossRef] [PubMed]

65. Fereday, J.; Muir-Cochrane, E. Demonstrating rigor using Thematic Analysis: A hybrid approach of inductive and deductive coding and theme development. Int. J. Qual. Methods 2006, 5, 80-92. [CrossRef]

66. LaDonna, K.A.; Taylor, T.; Lingard, L. Why open-ended survey questions are unlikely to support rigorous qualitative insights. Acad. Med. 2018, 93, 347-349. [CrossRef]

67. Fleiss, J.L.; Levin, B.; Paik, M.C. Statistical Methods for Rates and Proportions, 3rd ed.; Wiley \& Sons: Hoboken, NJ, USA, 2003; ISBN 978-0-471-52629-2. 
68. Altman, D.G. Practical Statistics for Medical Research; Chapman and Hall: London, UK, 1991; ISBN 0-412-27630-5.

69. Bereiter, C.; Scardamalia, M. The Psychology of Written Composition; Lawrence Erlbaum Associates: Hillsdale, NJ, USA, 1987; ISBN 0-85859-647-5.

70. Donahue, C.; Lillis, T. Models of writing and text production. In Handbook of Writing and Text Production; Jakobs, E.M., Perrin, D., Eds.; De Gruyter: Berlin, Germany, 2014; pp. 55-78, ISBN 978-3-11-022063-6.

71. Christie, F.; Unsworth, L. Developing dimensions of an educational linguistics. In Continuing Discourse on Language: A Functional Perspective; Webster, J., Matthiessen, C., Hasan, R., Eds.; Equinox: London, UK, 2006; pp. 217-250, ISBN 978-1-845-53113-3.

72. Rose, D. Genre in the Sydney school. In The Routledge Handbook of Discourse Analysis; Gee, J.P., Handford, M., Eds.; Routledge: London, UK, 2012; pp. 209-225, ISBN 978-04-1555-107-6.

73. Martin, J.R. Genre-based literacy programmes: Contextualizing the SLATE project. Linguist. Hum. Sci. 2013, 7, 5-27. [CrossRef]

74. Trujillo, F. Enseñar nuevas lenguas en la escuela: L1, L2, LE . . , NL [Teaching New Languages in School: L1, L2, LE,... NL]. Rev. Educ. 2007, 343, 71-91.

75. Lee, I. Classroom Writing Assessment and Feedback in L2 School Contexts; Springer: Singapore, 2017; ISBN 978-981-10-3924-9.

76. Wingate, U. The impact of formative feedback on the development of academic writing. Assess. Eval. High. Educ. 2010, 35, 519-533. [CrossRef]

77. Virinkoski, R.; Lerkkanen, M.-K.; Holopainen, L.; Eklund, K.; Aro, M. Teachers' ability to identify children at early risk for reading difficulties in Grade 1. Early Child. Educ. J. 2018, 46, 497-509. [CrossRef]

78. Myhill, D. Prior knowledge and the (re)production of school written genres. In Writing in Context(s). Textual Practices and Learning Processes in Sociocultural Settings; Kostouli, T., Ed.; Springer: New York, NY, USA, 2005; pp. 117-136, ISBN 978-0387242378.

79. Scallon, G. Des Savoirs Aux Compétences. Exploration en évaluation Des Spprentissages; De Boeck: Bruxelles, Belgium, 2015; ISBN 978-28-0418-785-9.

80. Vaquero, A. Recomendaciones internacionales para la mejora de competencias en educación obligatoria en España [International recommendations for the improvement of competences in compulsory education in Spain]. Rev. Av. Supervisión Educ. 2018, 29, 1-22. [CrossRef]

81. Koh, K.; Carol-Ann, L.E.; Luke, A.; Gong, W.; Tan, C. Developing the assessment literacy of teachers in Chinese language classrooms: A focus on assessment task design. Lang. Teach. Res. 2017, 22, 1-25. [CrossRef] 